\title{
A tribute to Professor Daniel Louër on the occasion of his retirement
}

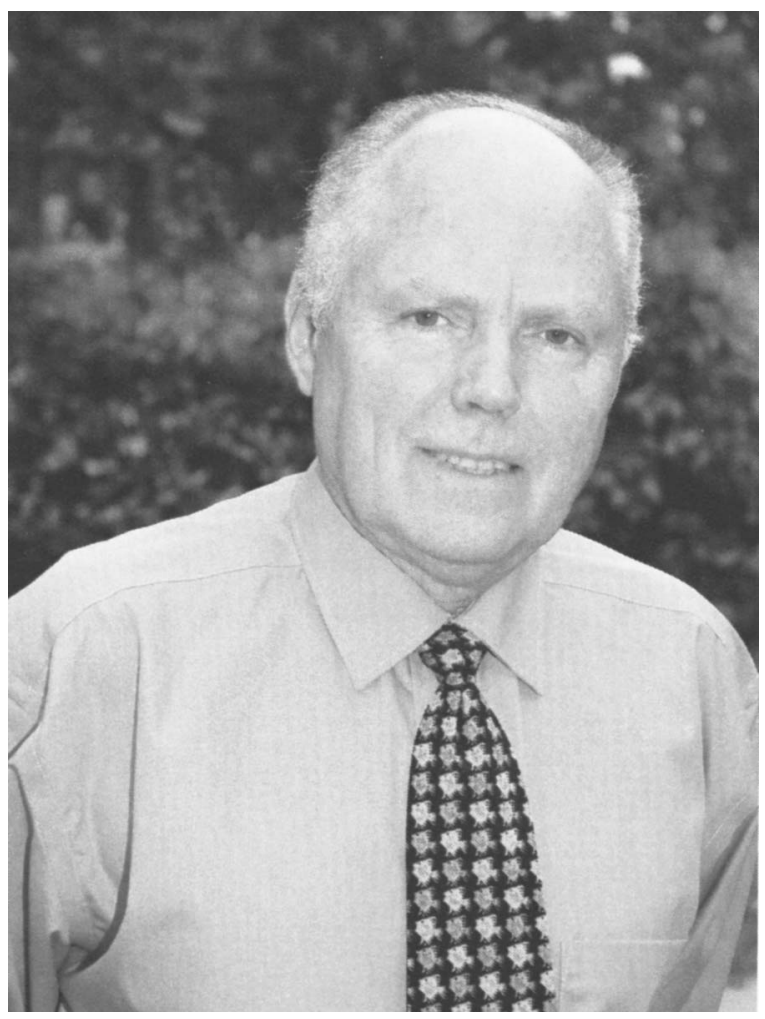

This special issue of Powder Diffraction is devoted to the outstanding career of Professor Daniel Louër, honorary Directeur de Recherche at the Centre National de la Recherche Scientifique (CNRS). After almost four decades of service, Professor Louër officially retired from the University of Rennes in April 2004. He remains active in the scientific community and presently serves as a Director-at-Large of ICDD. Since Daniel Louër has been a long-time contributor and supporter of Powder Diffraction Journal and was a member of its Editorial Advisory Board from 1985 and 2001, it seems appropriate that his work be recognized here. On behalf of the students, postdoctoral researchers, colleagues, and visiting scientists who have worked with Professor Louër, we are delighted to present a collection of invited articles embracing the fields of powder diffraction that Professor Louër contributed to. Indeed, all along his distinguished career (almost 250 publications and 50 invited conferences), Professor Louër's works have led to many outstanding contributions to the field of X-ray powder diffraction. These include his pioneering works in the development of the powerful dichotomy method for pattern indexing using the program DICVOL, the $a b$ initio structure determination of over 50 inorganic and organic compounds from laboratory X-ray sources since 1985, the use of monochromatic X-rays, the application of line profile analysis for investigating the microstructure of nanocrystalline materials, X-ray diffraction under nonambient conditions (such as thermodiffractometry) to inves- tigate the mechanisms of solid-state reactions, and many others. In 1990, Professor Louër chaired the International Programme Committee of the Powder Diffraction symposium of the International Union of Crystallography at Toulouse, France. This meeting is considered by many in the powder diffraction community as a precursor to the famous European Powder Diffraction Conferences (EPDIC), which is the only European conference completely dedicated to all aspects of the analysis of polycrystalline materials by diffraction methods.

Professor Louër received several professional awards for his pioneering works in powder diffraction. He was awarded an ICDD Fellow in 1990, the Hanawalt Award from ICDD for his outstanding contributions in the field of powder diffraction in 1992, and elected in 1996 Foreign Corresponding Academician of the Real Academia de Ciencias y Artes of Barcelona (Spain).

Professor Louër has been very active in other scientific activities. He has been an active ICDD member for decades, chaired the Data Collection and Analysis subcommittee and the X-ray task Group Committee, and serves on the Awards Committee of ICDD. He was also a consultant of the ICDD Board of Directors for many years and was elected a Director-at-Large in 2002. Professor Louër also served as the Secretary of the Commission on Powder Diffraction of IUCr, as a member of the famous Steering Committee of Collaborative Computational Project in Powder Diffraction 
and Small Molecule Crystallography (CCP14), and as a member of the Council of the French Crystallographic Association from 1990 and 1996. In addition to promoting conventional laboratory X-rays experiments, he also served as a member of the Review Committee in Chemistry of European Synchrotron Radiation Facility (E.S.R.F., Grenoble) and of the Programme Committee of the Chemistry Section of Laboratoire pour l'Utilisation du Rayonnement Electromagnétique (L.U.R.E., Orsay). Daniel Louër was also active in numerous professional programme committees of international congresses, chairman of technical sessions of IUCr, Denver X-ray Conference, EPDIC, ECM, and PPXRD meetings, and lectured frequently in many international schools and workshops.

Being recently asked about his schedule, Professor Louër answered that he is spending a lot of time on DICVOL and line-profile analysis. We anticipate exciting results from him and look forward to his continuous advices. As a Thesis Supervisor, Daniel Louër was an outstanding mentor and role model. "Il faut foncer" (go on!) was its recurrent adage that all his students and colleagues will always remember. Beyond his eager work, he was also enthusiastic about trekking on the weekends in the beautiful landscape and seacoast of Brittany. Coming back to the laboratory on Mondays he usually had new ideas to suggest to his students. He always enthusiastically introduced his students to the scientific community, and whenever possible and appropriate, he offered his students the chance to attend scientific conferences with him.

In appreciation of his outstanding contributions, we dedicate this special issue of Powder Diffraction to Professor Louër in honor of his retirement.

On behalf of all the contributing authors,

Nathalie Audebrand and Thierry Bataille Guest Editors

University of Rennes, Institute of Chemistry, Group of 'Cristallographie des Poudres et Réactivité des Solides' 